\title{
The Historical Records Survey in Iowa, 1936-1942
}

\section{Don Farran}

ALMOST FORTY YEARS HAVE PASSED since the last great attempt to discover and preserve the native legal and social records of the American people. It was in the 1930s that the Works Progress Administration under President Roosevelt, through Harry Hopkins and Howard C. Hunter as commissioners, attempted the largest program of discovery and restoration of critical public records of any nation in the world. It was called the Historical Records Survey. It ran through the critical years of the Depression of the 1930s and into the 1940s, and it provided work for tens of thousands who had no jobs.

Among the largest projects in number of persons employed was the survey of federal, state, and local records, later to include more than twenty allied national projects. Its first National Director and its originator in January 1936 was Dr. Luther H. Evans, a Texan who was later to become the Librarian of Congress, and still later the Director-General of UNESCO in Paris.

Now, as to our program and the progress.we have made. Our first and major objective is to make and publish an inventory of the public archives of all governmental units in the country. These include the archives of all federal agencies located in the 48 states, the state archives, the archives of the 3,066 counties, and the archives of cities, towns, townships, villages, and special districts of one kind and another. In addition, we inventory the archives of churches and other religious organizations, manuscript collections in historical societies, libraries and private hands, and books, pamphlets, and broadsides printed within the present limits of the 48 states and the District of Columbia prior to January 1, 1877 (in Arizona, Idaho, Montana, Nevada. North Dakota, South Dakota, Utah and Wyoming, prior to January 1, 1892, as printing started relatively late in these states.) (American Imprints Inventory). 
These are the principal tasks in which our more than 7,000 workers are engaged.'

Additionally, Dr. Evans described another facet of the Survey, that of preparation of a Comprehensive Compiliation of the Messages and Papers of the Presidents, from the inauguration of McKinley to the second inauguration of President Roosevelt. Also, Bibliographies of American History, American Literature, and Music in America also were in progress.

At the time of his address, in 1939, only 262 of the total of 3,066 counties remained without some work having been done. The Survey at that time had spread across the country into every state, utilizing the out-of-work personnel from $\mathrm{PhDs}$ to high school graduates who could be trained through procedures drawn up in the national office. Such procedures were arrived at after intensive consultation with many historians, librarians, and other authorities. Simplification to obtain the gross products which would be editorially handled in the state offices with final national approval was the main thrust. In general; records themselves were not copied, or abstracted, except the library cards in the American Imprints Inventory which were relevant. Records and other materials in storage in counties and states were handled only when they required cleaning and restoration and placement on shelving built by another WPA project. The records were inventoried by office and their location given after identification as to content and year.

By 1939 many inventories reached publication, as well as other types of historical matter. The requirement of careful rechecks made it necessary in many states to delay actual publication until following years. In its later years the Survey was almost buried following Pearl Harbor and the necessity of preparing the war efforts. And eventually, through lack of funds, the Survey, like all of the other Federal Arts Projects ("white-collar" projects, as they were known) was ended. But the work was too important to be lost in oblivion and ashes. There would be another day when work would be resumed, and our heritage properly preserved. Everyone knew that. And so almost forty years have passed, and we survivors of those days can only spin yarns about it.

'From an address delivered by Luther $H$. Evans before the 48th Continental Congress, National Society of the D.A.R., Washington D.C., April 19, 1939. 


\section{The Survey in Iowa}

It was in the summer of 1937 that Dr. Evans found me coasting along as an editor in the Federal Writers Project in Des Moines and kicked me upstairs to become the State Director of the Historical Records Survey in Iowa. There had been some malfunctions in that project and it was decided to appoint a new State Director. I realized, afterward, that no questions were asked regarding my political affiliations before my appointment. Perhaps it was known that I was conditioned to make up my mind and vote for the man rather than the party. Jessie Hanthorn, who was the head of all "white collar" projects in Iowa, may have passed the word to him.

When I tried to explain to Dr. Evans that I didn't know that the Historical Records Survey was in trouble, much less what might be wrong with it, he ordered me to check in at their office in the State Capitol building the following Monday and find out for myself.

My new office was large, luxurious, and was the office of the speaker when the Legislature was in session. This was their offyear. The staff was completely competent: George Atkinson and Bob Henderson (for twenty years the State Printer), Ray Meng, and in the outer offices a complete editing organization with a typing-pool with about twenty five typists to retype copy and cut the mineograph stencils for publication.

I made no changes. Instead, I asked them to continue their work as in the past and I would try to catch up with them as we went along. Most of the counties had been entered at least once by our workers, and some were being rechecked. A few counties were dragging their feet, apparently because of political reasons. One county in western Iowa, strongly Republican, was forbidding our workers access to the county records. At my request, the matter was handled by the Attorney General, and permission to enter was granted.

The Church Survey, under the Rev. William Hart, was progressing very well, turning up many little-known denominations operating within Iowa, some of them so small in congregations that they had no church buildings.

The Survey of Newspapers was hitting a mother-lode in Council Bluffs, under the capable direction of Mrs. Hudson. As a 
Southerner who disliked Mr. Lincoln, she had dug out of the newspaper files such items as that of the President's purchasing some thirteen parcels of land at the location where he was later to announce the Council Bluffs Transfer for the Union Pacific railroad was to be located. Her notation on that form was: "Honest Abe?"

Work on the American Imprints Inventory in Iowa was spotty, chiefly because only a limited number of workers could be allocated to it. But it was later on to reveal a great many new entries for the Iowa Imprints volume published in 1940.

By the summer of 1938 the project was running smoothly, with more and more material passing through the editorial department. Our first Inventory of county records was being stencilcut, and I took every one of the stencils to my hotel after work to read for corrections. There were, thanks to an excellent typingpool, almost no corrections necessary.

As any editor knows, seeing that first volume in completion is a happy day. The stencils were run and the pages assembled, with a slight over-run above the number we were required to provide. The national office had approved, and the Regional Director had read it. It was ready for publication in mid-summer 1938.

The Inventory, No. 18, Cherokee County, was finally published a year later, in 1939, under the direction of Dr. O. Clyde Sutherland, my successor, after months of trying to find a replacement for me.

\section{Federal Theatre}

Susan Glaspell, the Pulitizer-prizewinning playwright, had been Regional Director of the Federal Theatre's Midwest Play Bureau in Chicago, embracing Chicago and thirteen midwestern states. She was resigning because of ill-health, and possibly frustration. A successor was needed immediately.

John McGee, from Council Bluffs, Iowa, was the Regional Director of Federal Theatre. Jessie Hanthorn also was from Council Bluffs. Mrs. Florence Kerr was the deputy head of the "white collar" projects nationally, and was also from Iowa. And Harry Hopkins, head of WPA, was an Iowan. So . . in a rather strange coincidence, they looked around for an Iowan to take Miss Glaspell's place. And they zeroed in on me. I had recently written a biography of Richard Bennett, the actor, and that might have 
mislead them a bit. Besides, I had been acting in a sort of caretaker status at the Historical Records Survey in Iowa while it was approaching publication stages. But regional affairs seemed more important to WPA than state affairs, and so they put the finger on me. I had a short week in which to dissolve from the Survey, the Capitol, and my Iowa friends, and appear as the new Regional Director for the Midwest Play Bureau of Federal Theatre in Chicago.

The working conditions in the background of theatre fail to share in its glamour. Working conditions, with our Regional offices in the Penthouse of the Merchandise Mart, were ideal in Chicago. There were two of the largest theatres in the Loop under lease to Federal Theatre-legitimate theatre production had almost ceased to exist in that city as in most of America. Our "Swing Mikado," with an all-black cast, was being called by Chicago and Time magazine ". . . the finest musical in America. . ." It was the first time an actual national theatre had been in existence in this country, although national theatre had existed in some other nations for decades with government support. Actors and actresses all over America were working and eating and paying their rent. It seemed America was embarked upon a new road that might bring one of the major arts to the common people for the first time. And to become a working part of it seemed a delightful adventure, even with the twelve to fourteen hours a day I soon found were to be devoted to the job.

The next year in Federal Theatre left little time to be concerned with the previous year in the Historical Records Survey. I found the Survey retreating into the past, as something I was done with. My interest in it remained, but the Survey would now and for the future be in other hands.

It didn't work out that way. The Congress, even with the Recession tapering off, decided that theatre was a luxury America did not deserve. Federal Theatre was terminated in July of 1939, on the specious theory that its people might no longer be hungry and need work. Members of Congress continued to draw their ample salaries and ate in the best places in the nation's capital. ${ }^{2}$

${ }^{2}$ For more concerning Federal Theatre see my article in Books at Iowa. No. 18, April 1973, (Iowa City: University of Iowa). 


\section{American Imprints Inventory}

By early winter I was to undertake, with Douglas C. McMurtrie, the eminent authority on printing, the delivery to Rand McNally of the first biography of Johann Gutenberg, inventor of printing, ever written. The book was published the following summer, and was selected as the representative book for America in the world-wide celebration of the 500th Anniversary of the Invention of Printing.

Meanwhile, an editor was needed on the staff of the national office of the American Imprints Inventory there in Chicago. I accepted, and during that winter I edited both the Iowa Imprints volume and the Idaho Imprints volume. Some 15,000,000 cardslips covering early American printing had poured in from Historical Records Survey and American Imprints Inventory workers from the great and small libraries of this country to be sorted, arranged, edited, and finally published as check-lists.

In March of 1940 I was called to Washington D.C., where the National Director of the Historical Records Survey appointed me as one of his two assistants, and also appointed me National Director of the American Imprints Inventory to replace McMurtrie. A few days later I returned to Chicago to prepare for the move to Washington D.C.

\section{Historical Records Survey-National}

On my arrival in Washington D.C. in the spring of $1940 \mathrm{I}$ found the national offices of the Survey operating in most of the states. Dr. Luther H. Evans had gone on to the Library of Congress a year or more earlier to head its Legal Section, and was within a few years to become the Librarian of Congress. Mr. Sargent B. Child, who had been Dr. Evans' Assistant Director, had become the National Director of the Survey, with Dan Lacy as his Assistant. They had decided, unknown to me at the time, to have me replace McMurtrie as head of the Imprints Inventory, and bring it under closer supervision by the Survey in the national offices in the national capital. They also felt they needed an extra hand in running the increasing number of national projects being added to the Survey.

The states of Indiana and New Jersey had found sponsors so they could microfilm rather than publish inventories of county 
and state records. The other states were already approaching or actually publishing their county inventories, as well as many other subjects. Some 10,000 workers were on the payrolls of the Survey, with all the problems that entailed. But the Survey was at last running at full speed, showing results in publication form, and receiving considerable praise for the work across the country, from former critics and the public.

During the summer and autumn of 1940 some reticence appeared in the halls of Congress regarding allocation of funds for the coming year. After all, they pointed out, industrial production was increasing and the unemployment load was decreasing in many places. Some members, having succeeded in wiping out Federal Theatre, now looked for other Federals to eliminate.

In our offices in the old Auditorium building facing the pools between the North and South Interior Department monoliths, Sardy Child and Dan Lacy handled the Survey projects at those times when I was on field trips to the various states checking the HRSurvey and Imprints work. But as the Survey assumed more cognizance of projects where states were receiving less in federal funds, my field trips lessened. Just prior to Pearl Harbor we were badly under-staffed in the national offices, and the problems in the field were increasing. But more and more publications were appearing despite the loss of personnel in the states.

There appeared no way to lessen the work on inventory publication, but we were able to work out a simplified model of the Imprints Inventory and sent it out to Miss Beard in Chicago. She protested that such simplified check-lists would not fill the need adequately. My office ordered the new techniques substituted for the old style editing. And within a few months a flood of checklists of states poured in for final approval prior to publication. Where only a few of them had been published in the former years of the Inventory, by the following summer we had close to fifty published state check-lists of Imprints.

It was the events at Pearl Harbor that wrote an end to the future of the Federal projects and the Historical Records Survey and American Imprints. Almost immediately new projects such as Inventories of Civilian Defense were set up in the states, under the sponsorship of the Survey. Survey workers in the states were shifted to the new projects as a part of the national defense efforts, and published inventories of their efforts began appearing. 
Our own efforts to achieve publication of Survey and Imprints materials ground to almost a halt. Our Inventory of Church Records, the Graves Registration project, our projects in the Library of Congress, the Imprints Inventory work in libraries, and dozens of other projects gave way to removal of Army records in the Presidio in San Francisco to storage in Utah, and a huge project to remove all materials of cultural or historical value from libraries and museums along the seacoasts to safety 500 miles inland.

It was this latter project that left us without the wisdom and aid of Dan Lacy. He was placed in charge of it and transferred to the sponsor, the National Archives, as assistant to the director of the National Archives.

The other Federals were also feeling the weight of the war effort, some of them by staff reductions in the states and others by added new projects. The Federal Music project was among the first to be phased out. Then the Federal Arts project. By April of 1942 the Federal Writers project was being closed down. Because of our inventory facilities, the Historical Records Survey was kept in operation in the national offices until July, aiding the overall Research and Records national project to do as good a job of housekeeping of the Federal projects as possible. One day all of the good work would be revived, when the war was over. Everyone knew that.

It didn't happen that way. With limited storage space in the states, the huge masses of unpublished materials were moved to make-shift storage instead of becoming official accessions of state departments. Except for the materials the Library of Congress could accept because of limited space, those masses of materials, of research and preservation, are mostly in limbo, or were physically destroyed.

\section{Achievements}

In its report, dated September 1, 1941, the Federal Works Agency (WPA) issued a Check List of Historical Records Survey Publications. In it were listed as conclusively as possible at that date the numbers and types of actual publications. Among them were Inventories of County Archives, Inventories of State Archives, Inventories of Town and Municipal Archives, Inventories of Federal Archives in the State; the same for Miscellaneous Records, Manuscript Publications, Church Archives Publications 
and Church Directories, American Imprints Inventories, Newspapers, Portraits, Vital Statistics, Miscellaneous Publications, and Microfilming. The Report contained some seventy pages.

In Iowa the following inventories of county archives are listed as published: No. 1. Adair*, No. 14 Carroll, No. 18 Cherokee, No. 25 Dallas, No. 31 Dubuque, No. 39 Guthrie*, No. 47 Ida, No. 50 Jasper, No. 70 Muscatine*, No. 81 Sac, No. 87 Taylor*, No. 97 Woodbury. There were a great many others in various stages of completion or of rechecking before publication. No record appears in that Inventory of publication of State Archives Inventories in Iowa, or of Town and Municipal Archives.

There were Inventories of Federal Archives in Iowa reaching publication: The Federal Courts, The Department of the Treasury, The Department of Justice, The Department of the Navy, The Department of Agriculture, The Department of Commerce, The Farm Credit Administration, The Department of War, The Department of the Interior. There were some Miscellaneous Agencies brought to publication stage but not published.

No Church Archives publication is indicated, although that Survey in Iowa, headed by the Rev. William Hart, had done very extensive work. Of the American Imprints Inventories published, No. 15, A Check-List of Iowa Imprints 1838-1860, was published in December, 1940, by the national office in Chicago. I had completed editing it while an editor there. I had also edited No. 13, A Check List of Idaho Imprints 1839-1890, published that same year. That Check-List contained imprints translating the Nez Perce Indian language into the English alphabet by missionairies from Hawaii on a hand-press originally from Boston.

No Portraits Inventory was published in Iowa, but $A$ Guide to Public Statistics in Iowa was prepared for publication, although never published. In Miscellaneous Publications only one was published: Statutory Rights of Women in the United States, published in January 1940.

It was evident, after my departure from Iowa in the summer of 1938 , and after a considerable delay in appointing my successor, Dr. Sutherland, that a great deal of our edited materials were reaching publication, while other materials were being rechecked prior to approval by the national office. As mentioned previously

*Approved but not published by September 1, 1941. 
here, microfilming was confined chiefly to projects in Indiana and New Jersey. A majority of the county records were microfilmed in Indiana, and a great many state records were microfilmed in New Jersey. At one time in New Jersey I found a half-dozen large microfilming units in operation at a central location.

Corollary projects operating under the aegis of the Survey in state after state grew in numbers through the years. A few were already in existence before the Survey, and were taken under its wing by federal sponsorship. The New York Public Library's $A n$ notated Bibliography of American History was one such project. Dr. Evans was able to place it under Library of Congress sponsorship and save it from being abandoned.

Dr. George M. McFarland, its Editor-in-chief, had been the head, and continued on until March 1940 when he became an Assistant National Director of the Historical Records Survey. He was succeeded by Dr. William J. Wilson until the project was suspended in July 1941 because of lack of funds. At that time the entries had grown to some 27,000 , with a vast amount of unedited material on hand. True to its philosophy "... that to make material for research available was a mission of the Survey," it had given its support as long as possible.

At the suspension of the Historical Records Survey in the summer of 1942, some of the states were able to continue for a short time with their editing and publication. But the event of Pearl Harbor at the end of 1941 caused the Congress to discontinue even the small amount of funds for the Survey nationwide.

Almost immediately new projects in the states were originated and placed under the Historical Records Survey. For instance, the war effort required Inventories of Civilian Defenses in the states, and those new publications were rushed out through the Survey's facilities in the states. Many other projects appeared, some covering research for the Defense Department.

The Library of Congress accepted as much material as possible from the national offices of the projects. The National Archives accepted much of their national records of project operations. But out in the states there was mostly chaos. Few states had room in their buildings for storage of such vast quantities of research materials. Some provided temporary space, but by the war's end the materials so carefully researched and edited or unedited were on their way to oblivion. 
After the termination of the Historical Records Survey national offices, in the summer of $1942, \mathrm{Mr}$. Child was soon to be appointed the Cultural Attache in our embassy in London; Dr. Evans was before long to become the Librarian of Congress; Dan Lacy was to become the Acting National Archivist at the National Archives. And I was to accept a commission in the United States Navy.

Mr. Child's final report on the Survey shows more than 2,000 publications were completed, and more than fifty American Imprints Inventories were published. The latter was to be continued in operation throughout the war years, first in Chicago and then on removal of its more than $16,000,000$ library slips to the Library of Congress and its Union Catalog. That in itself deserves a separate article.

In her thesis for a Master of Arts degree at the University of Iowa, Trudy Huskamp Peterson (Mrs. Gary Peterson), has written a fine study of the operations of such federal projects during the Depression years. I commend it to those who desire a more indepth study of the Survey in Iowa.

\section{Bicentennial-Heritage '76}

When the Iowa American Revolution Bicentennial Commission was organized in 1973 it included among its parts the HERITAGE '76 section, concerned with the fields of history and archives. Its chairperson is Mrs. Velma Fry of Van Horne, Iowa. Operating closely with Jack W. Musgrove, director of the State Historical Department, Museum and Archives Division, and the librarian, Lida Lisle Greene, Mrs. Fry has organized most of the counties in Iowa with county chairpersons and volunteer research personnel trained to isolate official records, church and cemetery records, school records, county historical materials and other memorabilia which may be microfilmed for permanent preservation.

In the July 1974 issue of its Newsletter the IARBC explains in some detail the plans for such microfilming in a program to take approximately three years. From my knowledge of the old Survey, that period would seem less than required.

The microfilming is to be done by the Genealogical Society of the Church of Jesus Christ of Latter Day Saints of Salt Lake City, 
Utah, at no charge for the work. The original microfilm will be held by them in their underground library in Utah. A print of each microfilm will be deposited in the State Historical Building in Des Moines, Iowa for permanent preservation. Copies may be obtained by the counties at actual cost from the Society.

Work was commenced in the southern counties in September, 1974 , and then pushed gradually into the central and northern counties. A great deal of work has already been done in Missouri and Illinois by the Society's trained personnel. Microfilming is to be done generally in county courthouses where the materials are to be collected and made available to the Society's units. The Iowa Sixty-fifth General Assembly passed Senate File 1237 permitting the microfilming of certain public records up to 1910-for instance those concerning the vital statistics of county clerk offices: births, marriages, and deaths.

Such methods of preservation at the present time seem the most adequate means of making the American heritage accessible and safe for future generations. In the future they may be transferred to tape with immediate print-out to make duplication even more adequate.

One recalls those words carved at the main entrance to the National Archives building in Washington D.C.: "The Past Is Prologue. .." Looking back at the Historical Records Survey from the vantage point of almost forty years, and the tremendous efforts of those days to capture and preserve our origins before indifference turned them to dust, one can bless the present hopes and plans of the Bicentennial Commission, the governor, and the General Assembly for their foresight and wisdom. To future historians, our first 200 years may seem only a coffee-break in the annals of time. 
Copyright of Annals of Iowa is the property of State of Iowa, by \& through the State Historical Society of Iowa and its content may not be copied or emailed to multiple sites or posted to a listserv without the copyright holder's express written permission. However, users may print, download, or email articles for individual use. 